\title{
Decolonial thinking: A critical perspective on positionality and representations in island studies
}

\author{
Sarah Nimführ \\ Department of Cultural Studies, University of Art and Design Linz, Austria \\ sarah.nimfuehr@ufg.at (Corresponding author)
}

Greca N. Meloni

Department of European Ethnology, University of Vienna, Austria

greca.nathascia.meloni@univie.ac.at

\begin{abstract}
Scholars conducting research on and about islands face the challenge of countering the epistemic and methodological dominance of external perspectives on islands with an insular internal view, while also avoiding essentializing the island or reproducing Western perspectives. Islands have always been-and in some cases still are-confronted with a colonial gaze. Thus, to avoid producing hegemonic epistemology, we call for critical reflection on how islands are represented in our research, which theoretical concepts are referred to, and what knowledge is produced by applying them. Furthermore, we appeal for a reconsideration of the researcher's positionality within the field and their role in knowledge production. This special section is a contribution to the decolonial project within island studies.
\end{abstract}

Keywords: decoloniality, island studies, islandness, positionality, reflexivity

https://doi.org/10.24043/isj.178 • Received October 2021, Early Access November 2021

(C) Island Studies Journal, 2021

\section{The representation and conceptualization of islands}

Who has not imagined themselves suddenly settling down alone on a tropical beach made of shimmering white sand, surrounded by palm trees that hide a nearby native village? According to a bank advertisement (Figure 1), this is one of two life dreams: to invest in one's own business and to travel to a small, round, tropical island. Even if islands "come literally in all shapes and sizes" (Baldacchino, 2005, p. 247), this singular circular representation of an island can often be found because it is "easier to hold, to own, to manage or to manipulate" (Baldacchino, 2005, p. 247).

The allure of reducing islands to just a few stereotypical ideas is strong, in both media and in science. The 'island' becomes, then, a sort of paradise-like place, populated by rare species and exotic 'others'. It is then transformed into a subject of exploitation for tourism, environmental or natural resources, and any other purpose that serves to satisfy the needs of colonizer societies. This notion of the island is so deeply embodied in the visual imaginations of Western societies that even a Sardinian bank can use it as an effective advertisement to 
acquire more clients on an island that, despite its historical position, is already depicted as an untouched wild place in the hegemonic representation of the 'island'.

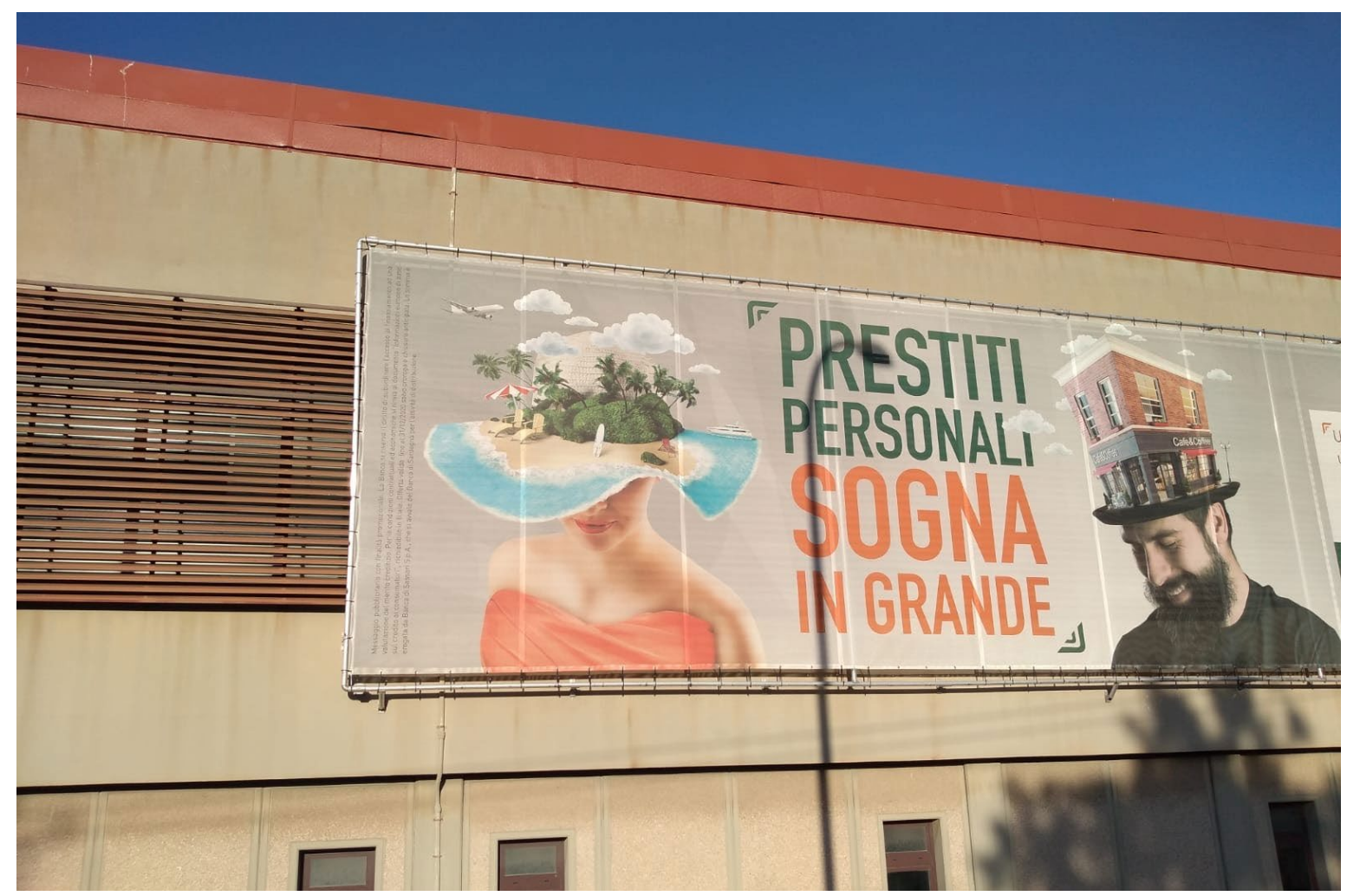

Figure 1: "Personal loans dream big"-Bank advertisement in Sardinia, Italy. Source: Greca N. Meloni, 2020.

This phenomenon shows how the representation of 'island' works in both directions, as a powerful gaze on the island itself, and as a tool to advocate a self-otherness (Bachis, 2015). In this vein, Adam Grydehøj (2018, p. 5) points out that islands have inhabited dreams and desires, and they have been associated with utopian attributes both by mainlanders and by islanders mostly living in noninsular areas. It is therefore impossible to consider island epistemologies without perspectives from the mainland. Due to the complexity and entanglement of island histories, the terms island and mainland cannot be clearly separated (Pöllath, 2018). Godfrey Baldacchino (2008, p. 37) also argues that a strict insider-outsider divide is untenable, since hybridity is the norm for islands. However, notions of islandness created on the mainland may collide with "alternative local visions of islandness" (Grydehøj, 2018, p. 5; Lee et al., 2017). In particular, this concerns stereotypical visions of island paradises, which (intentionally and unintentionally) are removed from any form of everyday life on islands. This results in some islanders astonishedly distancing themselves from the fact that they live in a supposed island paradise (Baldacchino, 2012, p. 58):

Some islanders are even confused by how they are seen as "paradises" by mainlanders, while they may struggle at home against un- and under-employment, aid dependency, brain and skill drain, waste management, water shortages, drug running or money laundering. 
Most often, islands occupy places in a noninsular perspective reserved for holidays, relaxation, and fun. Although the mainland can also offer breathtaking beaches and idyllic coasts (Fischer et al., 2007), it is apparently always the islands that people dream of. Attributes such as a "small physical size and warm water" (Baldacchino, 2008, p. 40) and "the island as paradise concept" (Royle, 2001, p. 16) are the central metaphors of island representation within Western discourse. Islands are thus "often subject to orthodox perspectives" (Farbotko, 2005, p. 280), which can hardly be relevant to the lives of their inhabitants. The obscuring of insular everyday life - a phenomenon termed by Baldacchino (2007, p. 2f.) as 'islanding'can be attributed on the one hand to the fact that the advertising and tourism industry has skillfully propagated a stereotype of the carefree, sunny island as a place of pleasant seclusion and relaxation. Indeed, many islands and island states produce the images of paradise themselves so "that they can 'sell' their sea, sun and sand" (Baldacchino, 2016) and meet the contemporary needs of privileged people to travel. On the other hand, 'islanding' can also be rooted in colonized ascriptions: An Austrian newspaper describes the Maltese archipelago as "the exotic in the Mediterranean" that convinces with its "exciting mixture of British order and Southern serenity" (see Figure 2; own translation). While the reference to the exotic is a clear form of 'islanding', the depiction of the British-Maltese relationship refers to a rather unique colonial bond. Since the beginning, the island state has maintained a paternalistic relationship with the former colonial power, which to this day has an impact on language, legislation, education, culture, and tourism. Instead of striving for full independence, the positive aspects of the colonial relations have been emphasized; this is what Baldacchino (2010) termed "upside down decolonization."

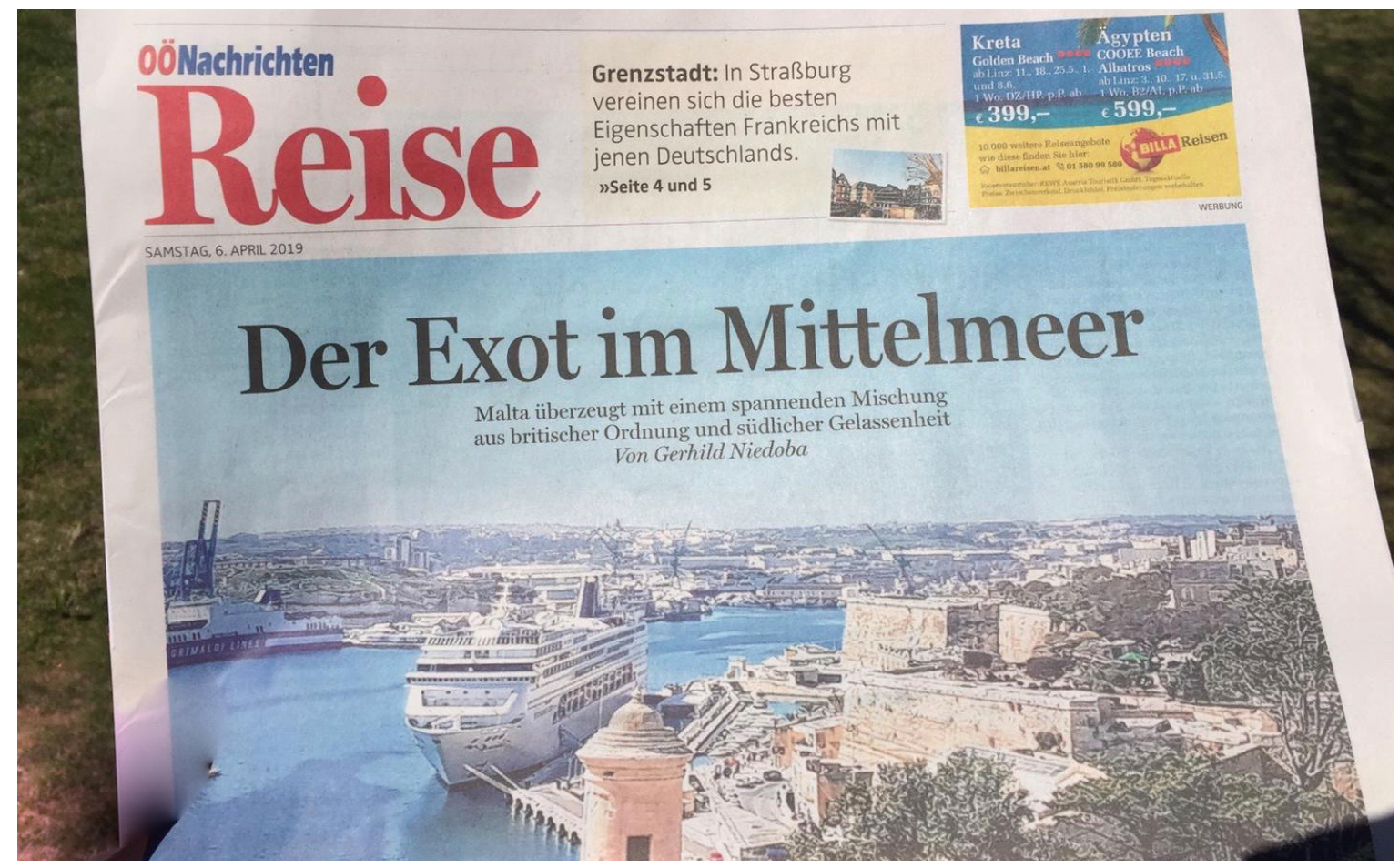

Figure 2: "The Exotic in the Mediterranean"-Austrian travelogue on Malta. Source: Sarah Nimführ, 2019. 
Scholars are not immune to cultural stereotypes and forms of 'islanding', thus, to avoid producing hegemonic perspectives, this special thematic section on 'Representing islands producing islandness' invites critical self-reflection on how islands are represented in our research, which theoretical concepts are referred to, and what knowledge is produced by their application. Furthermore, we encourage reflections on one's own positionality in the field.

\section{Self-reflections}

During our research, we too were confronted with different visions and perceptions of islands, by hegemonic epistemological approaches to cultural-anthropology research and writing, as well as by media images such as the ones shown in Figures 1 to 3. They underlined our own views of islands or were contrary to them and have therefore led to self-critical reflection on our own island imaginations and attributions.

During the Island Cities and Urban Archipelago conference in Zhoushan in 2018, Sarah Nimfuihr realized that she ascribed the attributes 'small size' and 'remoteness' to 'the island'. When Sarah traveled to Zhoushan, which is the largest island group in China, she had similar feelings to the protagonist in the short story by DH Lawrence (2002 [1927], p. 151), 'The Man Who Loved Islands', who stated that "an island, if it is big enough, is no better than a continent. It has to be really quite small, before it feels like an island." Although she was aware of the existence of numerous large islands and islands close to the mainland, the keyword 'island' initially triggered an imagination of smaller, more remote land masses. During the conference, which lasted several days, Sarah had no chance to view the sea. She did not have the feeling of being on an island. In her imagination, the sea and the island represented an inseparable unit, which is especially apparent on smaller islands. Only when traveling to and from the Chinese mainland by coach via the Jintang Bridge that connects Zhoushan with the city of Ningbo, could she find validation for her island imagination.

Greca N. Meloni was born on and grew up in Sardinia, Italy. To her, the fact that Sardinia, the second-largest island in the Mediterranean, cannot be reached without a plane or a ship has always been an implicit fact, so much so that living and researching on an island represented such a normality or matter of course for her that she initially did not include the island's theoretical circumstances in her research. It was only when she met Sarah, in exchanges about their current research projects, that she realized that the island with "the sea around" (Angioni, 2003) represented a way of being in the world not only for herself, but especially for the people with whom she was conducting research. As she herself admitted, to be an islander is such an obvious thing that to mention it when you are introducing yourself to someone else would be as if one were to remark that as a human you have two legs and two arms.

This self-reflexive insight shows that if we are not aware of our own ascriptions, we transfer them-perhaps unintentionally - to our research object and subject. Particularly in the early twentieth century, when island research was popular among ethnologists and geographers (King, 2009, p. 55), the view of islands was characterized by an understanding of a supposed island microcosm and ideal laboratory research. Even today, stereotypical ascriptions can be found in some research on and about islands (for a critical discussion, see Nimführ \& Otto, 2020, p. 190). These ascriptions neglect an already long and ongoing vivid debate within today's interdisciplinary field of island studies (examples include Baldacchino, 
2008; Chandler \& Pugh, 2021; Grydehøj, 2015; Hayward, 2012; Pugh, 2013a; Sheller, 2009; Stratford et al., 2011). Many concepts and thoughts that have been developed in this debate are influenced by Epeli Hau'ofa's (1994) evocation of "a sea of islands," that challenges hegemonic binaries and advocates a reconceptualization of the Pacific. His work is considered a critical reference point in the decolonization movement, and, even after more than 25 years, it has had a major impact in the region and beyond. A comprehensive overview of the development of island studies and the various research strands can be found in Grydehøj's (2017) editorial introduction 'A future of island studies'. A new strand of research in island studies is devoted to decolonial thinking (examples include Aldrich \& Johnson, 2018; Connell, 2016; Grydehøj, 2016; Nadarajah \& Grydehøj, 2016; Joseph, 2020; Pugh, 2013b; Pyndiah, 2016; Rodd, 2016; Teiawa, 2020), to which this special thematic section aims to contribute as we discuss in more detail below.

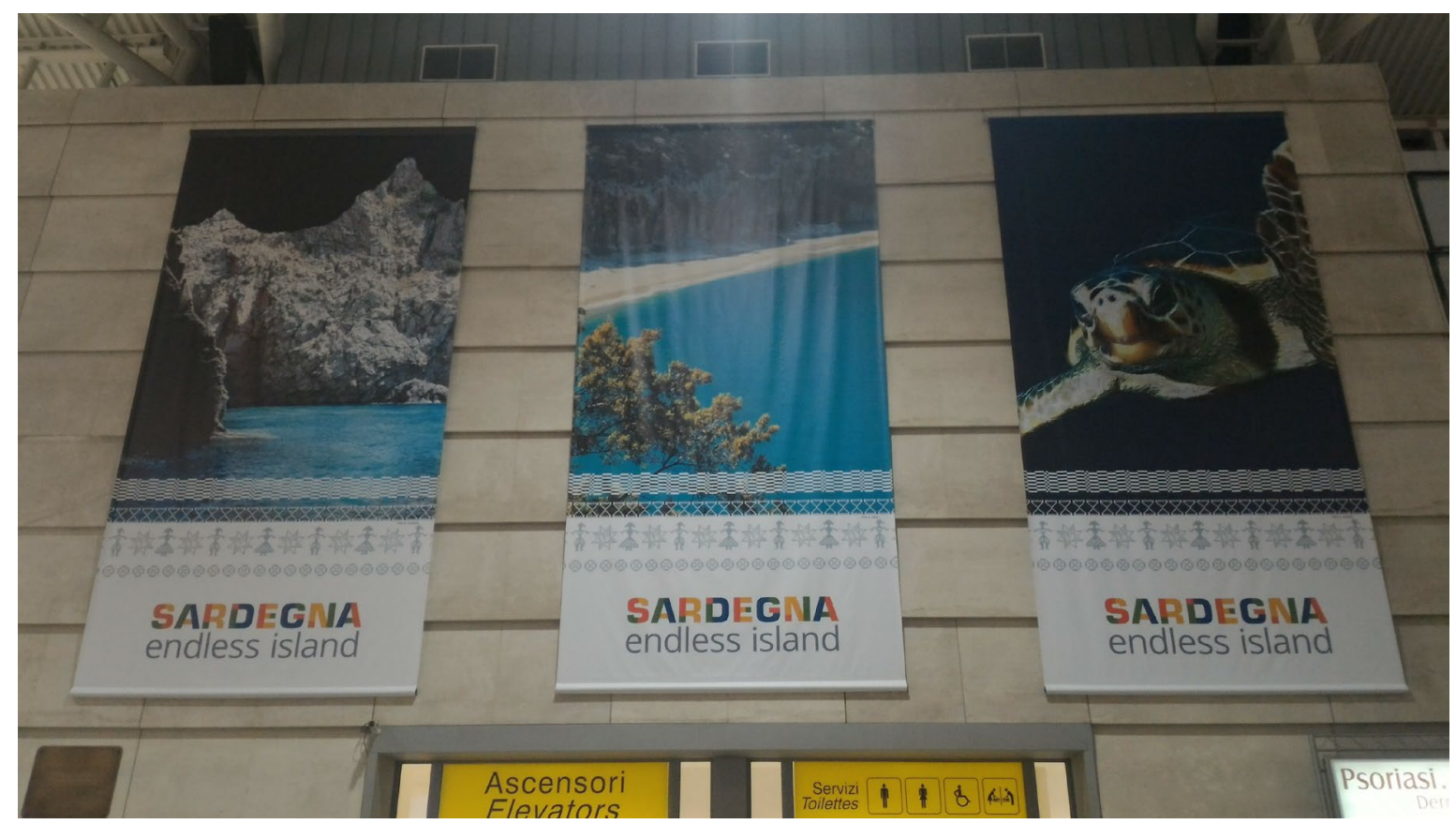

Figure 3: The "endless island" of Sardinia, Cagliari Airport. Source: Greca N. Meloni, 2018.

\section{Producing islandness-positionality in the colonial matrix of power}

As we have shown above, perceptions of the island are characterized by phenomena that are self-evident in the sense that the notions of the island are taken for granted; they are overand underestimated, and they are also marked by exoticism linked to Eurocentric modes of thinking. It is therefore important that scholars not only analyze whether externally ascribed characteristics of the island exist within the framework of their research, but that they also try to deconstruct and decolonize their own island imaginations and are "aware of their own positions within the colonial matrix of power" (Grydehøj, 2018, p. 3). This is particularly important when island research is focused on formerly colonized islands that still have colonial or neocolonial relations with the metropolitan powers, with the researchers coming from these metropolises. Conducting research as a scholar from the Global North in countries in the Global South can be understood as a continuation of colonial practice that reproduces unequal power relations. However, this danger may also exist when researchers are perceived 
as "translating individuals" (Ang, 2001) or "the outsider within" (Nadarajah, 2007) due to crosscultural and transnational ways of working and living and self-positioning. Yaso Nadarajah (2007, p. 128) reflects that:

Moving between cultures and languages emphasizes this translating process of living, mapping the complexity of having to simultaneously negotiate the space between mainstream Western academic concerns and my own intellectual and geographical/spatial dislocation.

In this vein, Nadarajah and Grydehøj (2016, p. 441f.) call for "decolonial island studies" instead of reproducing Eurocentric research or seeking to develop island research that follows "Western ways of knowing and expressing knowledge" (Grydehøj, 2018, p. 7). 'Decoloniality' emerged in the mid-1990s mainly through the Latin American research collective Modernidad/Colonialidad, which was formed by the leading critical intellectuals Enrique Dussel, Aníbal Quijano, and Walter Mignolo. They criticize a Eurocentric understanding of the world and focus on untangling knowledge production from a dominating Eurocentric episteme (Escobar, 2003). The analytical category of 'coloniality' represents an epistemic node from which power and knowledge relations in the modern world can be viewed (Quijano, 2007). In this vein, decolonial thinking can contribute to efforts to "step beyond the potential neocolonial trap of "universalism"” (Aluli Meyer, 2003, p. 146) as knowledge and practices are understood as pluriversal (De La Cadena \& Blaser, 2018). From this pluriversal perspective, relationality becomes core by being both centrifugal and centripedal, always in view of relations and with respect for opacity (Glissant, 1990). According to Macarena Gómez-Barris and May Joseph (2019, p. 6) "a relational and archipelagic approach (Pugh, 2018) has opened up complex models for rethinking frameworks of island ontologies," that require "inventing nuanced and innovative ways of sensing relations that are both the cause and opportunity for a decolonial island praxis."

Academic definitions of 'decolonial thinking' and 'decoloniality' as well as actual processes of overcoming colonial power structures vary, but they generally question how certain people and places are marginalized or excluded by practices of knowledge formation, particularly by favoring what could be universalized as knowledge of the (often-white) Global North over views and knowledge of the world of the (often-racialized) Global South (de Leeuw \& Hunt, 2018, p. 3). Thus, "decoloniality is first and foremost liberation of knowledge" (Mignolo, 2018, p. 146) due to its delinking from epistemic Eurocentrism and undertaking an "epistemological reconstitution" (Quijano, 2007, p. 176).

We understand decolonial island studies as a "complex and multifaceted process that is best conceived as a journey rather than a destination" (Dumontet et al., 2019, p. 197). By associating decoloniality as a journey, the individual (learning) process is considered, which can be subject to constant change and is always in the process of becoming, and so needs to be constantly reflected upon. In this sense, Nadarajah and Grydehøj (2016) refer to their special thematic section on 'Island decolonization' as a decolonial project within island studies that can contribute significantly to already-existing decoloniality theories and practices (others include Abu-Lughod, 2008; Mignolo \& Walsh, 2018; Moraña, Dussel, \& Jáuregui, 2008; Sandoval, 2000; Smith, 2012). Previous decolonial projects have sought to raise critical 
awareness and understanding of the impact of colonization on knowledge and its production, to stimulate reflection and action that leads to change, and to challenge and reverse the forces of colonialism by restoring and promoting indigenous cultural practices, beliefs, and values. Yet, as Nadarajah and Gyrdehøj (2016, p. 442f.) note, there are still tensions to be seen in attempts to adopt a decolonial island studies perspective, "that not only serves the needs of colonized island peoples but that also serves them 'on their own terms.",

Decolonial thinking also means decolonizing methodologies and reflecting the "geopolitics of knowledge" (Mignolo, 2011, p. 138). Western research is deeply enmeshed in colonial power structures and forms of othering, which is why it needs to be decolonized through strategies of averting and reversing the dominant scientific gaze (Traverso, 2021). To counteract the possible danger of Eurocentric knowledge production, "research through imperial eyes" (Smith, 2012, p. 44) has to be deconstructed, e.g., by giving special consideration to perspectives and "theories from the South" (Comaroff \& Comaroff, 2012) and by reflecting on systems of classification and representation in order to facilitate effective ways of sharing knowledge between all involved actors. The community researcher Linda Tuhiwai Smith criticizes how, in research especially, the concept of distance has led to the reproduction of a hegemonic world view as it embodies a power relationship: That is, by retaining an 'objective' distance from the environment and community to be researched, the researcher's knowledge will become the only permissible knowledge (Smith, 2012, p. 58).

At the same time, there is the question of who has the right to use decolonizing methods. When non-marginalized researchers research marginalized communities, they have to be very critical of their own standpoints (Grydehøj et al., 2021, p. 9; Smith, 2012, p. 214). A decolonial perspectivation of the field of research thus also always means denaturalizing global orders and power relations and deconstructing the power-knowledge complexes that have historically grown. Collaborative knowledge production can contribute to breaking down this divide. Such efforts may include collaborating with "Indigenous scholars, decolonial thinkers, poets and artists" (Gómez-Barris \& Joseph, 2019, p. 2), as well as seeking a more collaborative way of working by discussing observations and analyses or creating collaborative writing with fieldwork interlocutors, which can permeate the dichotomy between the researchers and the actors in the field and establish a partnership between the researcher and the individuals "to be researched" (Nimführ, 2020). This could lead to (academic) knowledge production that acknowledges "collaborators as co-designers of knowledge" (Itchuaqiyaq \& Matheson, 2021, p. 9) and avoids a Eurocentric perspectivation (Decoloniality Europe, 2013; Shanley \& Laird, 2002). As part of her research, Greca created a blog in which all participants of the community of beekeepers in Sardinia have equal writing rights and can share knowledge and perspectives on beekeeping issues (see Abieris e Abis, 2021; Meloni, 2018). And Sarah shared her interpretative power by enabling (refugee) research partners to write and comment in her research diary, but also by publishing scientific papers together with them (see Nimführ \& Sesay, 2019).

Nevertheless, it is important to consider the limitations of these emerging practices. After all, decolonial practices are largely carried out by Euro-American and diasporic scholars in the metropolises, who benefit from these places of knowledge production and the direct material effects of this privilege. María do Mar Castro Varela and Nikita Dhawan (2015, p. 286; remark by the authors) speak critically here of a "post- [and de]colonial theory industry," and others even refer to it as a "career advancement machine" (Bahri, 1995, p. 71, qtd. in 
Castro Varela \& Dhawan, 2015, p. 289; own translation). In light of our awareness of these problematic issues, it is therefore necessary to highlight the importance of positioning expert knowledge appropriately with regard to the needs of colonized and Indigenous people (Nadarajah \& Grydehøj, 2016, p. 437; Unwin \& Tuterangiwhiu, 2021). In this vein, Cana Uluak Itchuaqiyaq and Breeanne Matheson (2021, p. 9; remark by the authors) suggest selfevaluating "the appropriateness of a decolonial frame for their [scholars'] own work" and, if it does not have any significant benefits to Indigenous/colonized stakeholders and communities, placing it "inside another ideological frame such as feminist, social justice, anticolonialism, critical race theory, or other related theoretical frames."

The challenge for the decolonial island studies project is to take into account the rich spectrum of island perspectives and their diversity in knowledge production, while being aware of complexities and tensions in order to avoid remarginalizing already marginalized actors.

\section{Content review}

This special thematic section on 'Representing islands - producing islandness: Rethinking identities, mobilities, and relations in island research' arose out of a workshop organized by us and hosted by the Department of European Ethnology at the University of Vienna in November 2019. The workshop, entitled 'Anthropology of Islands: Reflecting Islandness from a Historical and Cultural Studies Perspective', brought together numerous international and interdisciplinary scholars and sought to reflect on the production of islandness in our research projects.

In this special thematic section, we encouraged the authors to critically reflect on how islands are represented and islandness is produced by us as researchers both in the methodologies with which we engage and the theories we apply to our fields. Based on empirical and theoretical findings, the papers address the following questions: Which theoretical concepts do we refer to? How do we deal with situated and changing manifestations and meanings of islands? Which ascriptions of the island do we observe and how can we deconstruct them? How do we deal with the reproduction of essentializations of the island? To what extent do we take the "geo-politics of knowledge" (Mignolo, 2011) into account in our research? What is our positionality and role in knowledge production?

The seven papers presented in this special thematic section consider a diverse mix of cases and contexts enabling a reflective analysis of one's own island research and positionality. Daniele Gavelli and Myriam Mereu introduce the concept of 'islanderscope' by considering the role of cinematic landscapes disclosing the tropes of islandness reciprocally attributed both to the protagonist and the main cultural and geographical features of Sardinia by using the example of the film Cainà. Martina Giuffrè deals with the changes in Cape Verdean identity perception related to islandness and migration issues from a gender perspective. Delilah Griswold ethnographically analyzes the framings of island vulnerability and climate catastrophe by focusing on climate adaption practices on Fiji. Eva-Maria Knoll investigates her own attempts to unravel her involvement in island-island relations and representations, by referring to her studies on thalassaemia in the Maldivian archipelago. Gaspare Messana attempts to investigate how global phenomena such as mass tourism and transnational migration are impacting and changing the traditional hospitality of Sardinians. Sarah Nimfuihr and Laura Otto challenge universal understandings of smallness against the backdrop of their 
research in Malta by exploring how island-related smallness is produced and used situationally in the context of (im)mobility. Pavla Šimková analyzes the relationship between urban islands and their 'mother city' to explore the specific interactions between coastal islands and urban centers, taking Boston and its harbor archipelago as an example.

These papers contribute to the decolonial project within island studies as initiated by Nadarajah and Grydehøj (2016). The collection adds new perspectives to the works that came before, seeking to encourage retheorizing and reflections on applied concepts and on one's own positionality within research, thus contributing to decolonial praxis.

\section{Acknowledgments}

We thank all the authors who contributed to this thematic section, as well as those who participated in the previous process. We are grateful for the language editing and enlightening comments by Ernest Stanley on earlier versions of this introduction, which sharpened our thoughts on decoloniality. The idea for this thematic section developed from the workshop 'Anthropology of Islands: Reflecting Islandness from a Historical and Cultural Studies Perspective' at the University of Vienna, 22-23 November 2019. We thank the participants for the valuable insights into their island-research projects and the rich discussions that also helped to shape this thematic section. Many thanks to Adam Grydehøj and Jonathan Pugh for supervising the process of assembling the thematic section. Finally, we thank Andrew Hodges for language editing of our final work and the Center for International and Transnational Area Studies (CITAS) at the University of Regensburg, Germany, for funding the editing.

\section{References}

Abieris e Abis (2021). Anthropologia dell'Apicoltura in Sardegna. https://www.fareapicoltura.net/

Abu-Lughod, L. (2008). Writing women's world: Bedouin stories. Berkeley \& Los Angeles: University of California Press.

Aldrich, R., \& Johnson, M. (2018). History and colonisation. In G. Baldacchino (Ed.). The Routledge international handbook of island studies. A world of islands (pp. 153-72). London \& New York: Routledge.

Aluli Meyer, M. (2003). Our own liberation: reflections on Hawaiian epistemology. The Contemporary Pacific, 13(1), 124-48. https://doi.org/10.1353/cp.2001.0024

Ang, I. (2001). On not speaking Chinese. Living between Asia and the West. London \& New York: Routledge.

Angioni, G. (2003). Il mare intorno. Palermo: Sellerio.

Bachis, F. (2015). Diversi da chi. Note su appartenenza e politiche dell'identità. In L. Marrocu, F. Bachis, \& V. Deplano (Eds.). La Sardegna contemporanea. Idee, luoghi, processi culturali (pp. 695-719). Roma: Donzelli.

Baldacchino, G. (2016, September 27). On the branding and reputation of islands. The Place Brand Observer. Retrieved from https://placebrandobserver.com/branding-islands/

Baldacchino, G. (2012). The lure of the island. A spatial analysis of power relations. Journal of Marine and Island Cultures, 1(2), 55-62. https://doi.org/10.1016/j.imic.2012.11.003 
Baldacchino, G. (2010). "Upside down decolonization” in subnational island jurisdictions: Questioning the "post" in postcolonialism. Space and Culture, 13(2), 188-202. https://doi.org/10.1177\%2F1206331209360865

Baldacchino, G. (2008). Studying islands: On whose terms? Some epistemological and methodological challenges to the pursuit of island studies. Island Studies Journal, 3(1), $37-56$.

Baldacchino, G. (2007). Introducing a world of islands. In G. Baldacchino (Ed.). A world of islands: An island studies reader (pp. 1-29). Charlottetown, Canada \& Luqa, Malta: University of Prince Edward Island, Institute of Island Studies and Agenda Academic.

Baldacchino, G. (2005). Editorial: Islands: Objects of Representation. Geografiska Annaler. Series B, Human Geography, 87(4), 247-51. https://doi.org/10.1111/j.0435_ $\underline{3684.2005 .00196 . x}$

Castro Varela, M. do, \& Dhawan, N. (2015). Postkoloniale Theorie. Eine kritische Einführung. Bielefeld: transcript.

Chandler, D., \& Pugh, J. (2021). Islands and the rise of correlational epistemology in the Anthropocene: Rethinking the trope of the 'canary in the coalmine.' Island Studies Journal, 16(1), 209-28. https://doi.org/10.24043/isj.119

Connell, J. (2016). Greenland and the Pacific Islands: An improbable conjunction of development trajectories. Island Studies Journal, 11(2), 465-84.

Comaroff, J., \& Comaroff, J.L. (2012). Theory from the South. Or, how Euro-America is evolving toward Africa. Boulder \& London: Paradigm Publishers.

Decoloniality Europe (2013, May). Charter of Decolonial Research Ethics. Decolonidad Europa/Decoloniality Europe. Retrieved from: https://decolonialityeurope.wixsite.com/decoloniality/charter-of-decolonialresearch-ethics

De La Cadena, M., \& Blaser, M. (Eds.) (2018). A world of many worlds. Duke University Press. de Leeuw, S., \& Hunt, S. (2018). Unsettling decolonizing geographies. Geography Compass, 12(7). https://doi.org/10.1111/gec3.12376

Dumontet, M., Kiprop, M., \& Loewen, C. (2019). Steps on the path towards decolonization: A reflection on learning, experience, and practice in academic support at the University of Manitoba. Canadian Journal for Studies in Discourse and Writing/Rédactologie, 29, 196216. https://doi.org/10.31468/cjsdwr.745

Escobar, A. (2003). Mundos y Conocimientos de otro modo. El programa de investigación modernidad/colonialidad latinoamericano. Tabula Rasa, 1, 51-86.

Farbotko, C. (2005). Tuvalu and climate change: Constructions of environmental displacement in the 'Sydney Morning Herald'. Geografiska Annaler. Series B, Human Geography, 87(4), 279-93.

Fischer, N., Müller-Wusterwitz, S., \& Schmidt-Lauber, B. (2007). Der neue Blick auf die Küste (Einleitung). In N. Fischer, S. Müller-Wusterwitz, \& B. Schmidt-Lauber (Eds.). Inszenierungen der Küste (pp. 3-15). Berlin: Reimer.

Giuffré, M. (2021). Female migration in the Cape Verde Islands: from islandness to transnationalism. Island Studies Journal, 16(2), 117-135. https://doi.org/10.24043/isj.180

Glissant, É. (1990). Poétique de la Relation. Paris: Gallimard. 
Gómez-Barris, M., \& Joseph, M. (2019). Introduction- Coloniality and islands. Shima, 13(2), 1-10. https://doi.org/10.21463/shima.13.2.03

Griswold, D. (2021). Growing hope: Island agriculture and refusing catastrophe in climate change adaptation in Fiji. Island Studies Journal, 16(2), 136-155. https://doi.org/10.24043/isj.181

Grydehøj, A. (2018). Hearing voices: colonialism, outsider perspectives, island and Indigenous issues, and publishing ethics. Island Studies Journal, 13(1), 3-12. https://doi.org/10.24043/isj.54

Grydehøj, A. (2017). A future of island studies. Island Studies Journal, 12(1), 3-16. https://doi.org/10.24043/isj.1

Grydehøj, A. (2016). Navigating the binaries of island independence and dependence in Greenland: decolonization, political culture, and strategic services. Political Geography, 55(1), 102-12. https://doi.org/10.1016/j.polgeo.2016.09.001

Grydehøj, A. (2015). Island city formation and urban island studies. Area, 47(4), 429-435. https://doi.org/10.1111/area.12207

Grydehøj, A., Bevacqua, M. L., Chibana, M., Nadarajah, Y., Simonsen, A., Su, P., Wright, R., \& Davis, S. (2021). Practicing decolonial political geography: Island perspectives on neocolonialism and the China threat discourse. Political Geography, 85, 102330. https://doi.org/10.1016/j.polgeo.2020.102330

Hau'ofa, E. (1994). Our sea of islands. The Contemporary Pacific, 6(1), 147-161.

Hayward, P. (2012). Aquapelagos and aquapelagic assemblages. Towards an integrated study of island societies and marine environments. Shima, 6(1), 1-11.

Itchuaqiyaq, C.U., \& Matheson, B. (2021). Decolonizing decoloniality: Considering the (mis)use of decolonial frameworks in TPC scholarship. Communication Design Quarterly, 9(1), 20-31. https://doi.org/10.1145/3437000.3437002

Joseph, M. (2020). Islands, history, decolonial memory. Island Studies Journal, 15(2), 193-200. https://doi.org/10.24043/isj.138

King, R. (2009). Geography, islands and migration in an era of global mobility. Island Studies Journal, 4(1), 53-84.

Knoll, E.-M. (2021). The 'other' within: Striving for health equity in the Maldives. Island Studies Journal, 16(2), 18-38. https://doi.org/10.24043/isj.177

Lawrence, D.H. (2002). The man who loved islands. In D. Mehl \& C. Jansohn (Eds.). The Cambridge Edition of the Works of D.H. Lawrence. The woman who rode away and other stories (pp. 151-73). Cambridge: Cambridge University Press.

Lee, S.H., Huang, W.H., \& Grydehøj, A. (2017). Relational geography of a border island: local development and compensatory destruction on Lieyu, Taiwan. Island Studies Journal, 12(2), 97-112. https://doi.org/10.24043/isj.33

Meloni, G.N. (2018). Saperi condivisi, saperi in conflitto. Etnografia dell'apicoltura in Sardegna. Antropologia Pubblica, 4(2), 65-83.

Mereu, M., \& Gavelli, D. (2021). Cainà: Islandscape and 'islanderscope' on screen. Island Studies Journal, 16(2), 59-79. https://doi.org/10.24043/isj.172

Messana, G. (2021). Hospitality and exchange: Identity relationships between 'natives' and foreigners' in Sardinia. Island Studies Journal, 16(2), 97-116. https://doi.org/10.24043/isj.176 
Mignolo, W.D. (2018). The conceptual triad. Modernity/coloniality/decoloniality. In W.D. Mignolo \& C.E. Walsh (Eds.). On decoloniality. Concepts, analytics, praxis (pp. 135-52). Durham: Duke University Press.

Mignolo, W.D. (2011). The darker side of Western modernity. Global futures, decolonial options. Durham NC \& London: Duke University Press. https://doi.org/10.1215/9780822394501

Moraña, M., Dussel, E., \& Jáuregui, C.A. (Eds.) (2008). Coloniality at large: Latin America and the postcolonial debate. Durham: Duke University Press.

Nadarajah, Y., \& Grydehøj, A. (2016). Island studies as a decolonial project. Island Studies Journal, 11(2), 437-446.

Nadarajah, Y. (2007). The outsider within - Commencing fieldwork in the Kuala Lumpur/Petaling Jaya Corridor, Malaysia. International Journal of Asia-Pacific Studies, 3(2), 109-32.

Nimfuihr, S. (2020). Reflections on collaborative knowledge production in the context of forced migration. Feministische GeoRundmail, 83, 29-33.

Nimführ, S., \& Otto, L. (2021). (Un)Making smallness: Islands, spatial ascription processes and (im)mobility. Island Studies Journal, 16(2), 39-58. http://doi.org/10.24043/isj.173

Nimfuihr, S., \& Otto, L. (2020). Doing research on, with and about the Island: Reflections on Islandscape. Island Studies Journal, 15(1), 185-204. https://doi.org/10.24043/isj.107

Nimfuihr, S., \& Sesay, B. (2019). Lost in limbo? Navigating (im)mobilities and practices of appropriation of non-deportable refugees in the Mediterranean area. Comparative Migration Studies, 7(26). https://doi.org/10.1186/s40878-019-0132-8

Pugh, J. (2013a). Island movements. Thinking with the archipelago. Island Studies Journal, $8(1), 9-24$.

Pugh, J. (2013b). Speaking without voice: Participatory planning, acknowledgement, and latent subjectivity in Barbados. Annals of the Association of American Geographers, 103(5), 1266-1281. https://doi.org/10.1080/00045608.2012.706571

Pyndiah, G. (2016). Decolonizing Creole on the Mauritius Islands: Creative practices in Mauritian Creole. Island Studies Journal, 11(2), 485-504.

Pöllath, M. (2018). Revisiting island decolonization: the pursuit of self-government in Pacific island polities under US hegemony. Island Studies Journal, 13(1), 235-250. https://doi.org/10.24043/isj.46

Quijano, A. (2007). Coloniality and modernity/rationality. Cultural Studies, 21(2-3), 168178.

Rodd, A. (2016). Adapting postcolonial island societies: Fiji and the Solomon Islands in the Pacific. Island Studies Journal, 11(2), 505-520.

Royle, S.A. (2001). A geography of islands: Small island insularity. London \& New York: Routledge.

Sandoval, C. (2000). Methodology of the oppressed. University of Minnesota Press.

Shanley, P., \& Laird, S.A. (2002). Giving back: Making research results relevant to local groups and conservation. In S.A. Laird (Ed.). Biodiversity and traditional knowledge. Equitable partnerships in practice (pp. 102-124). London: Earthscan. 
Sheller, M. (2009). Infrastructures of the Imagined Island: Software, Mobilities, and the Architecture of Caribbean Paradise. Environment and Planning A: Economy and Space, 41(6), 1386-1403.

Šimková, P. (2021). "Minutes away, worlds apart”: The changing imagination of the Boston Harbor Islands. Island Studies Journal, 16(2), 80-96. https://doi.org/10.24043/isj.169

Stratford, E., Baldacchino, G., McMahon, E., Farbotko, C., \& Harwood, A. (2011). Envisioning the archipelago. Island Studies Journal, 6(2), 113-130.

Smith, L.T. (2012). Decolonizing methodologies. Research and indigenous peoples. London: Zed Books.

Teaiwa, K. (2020). On decoloniality: a view from Oceania. Postcolonial Studies, 23(4), 601603. https://doi.org/10.1080/13688790.2020.1751429

Traverso, A. (2021, July 7). Decolonizing the visual: State violence and activist media in Chile and Australia [Conference presentation]. Memory Studies Association Annual Conference, 2021.

Unwin, H., \& Tuterangiwhiu, T.R. (2021, September). He kāinga rangahau: Developing a framework for research that is just and equitable for indigenous peoples. Cawthron. https://www.cawthron.org.nz/research/he-kainga-rangahau/ 
Sarah Nimführ \& Greca N. Meloni

THIS PAGE INTENTIONALLY LEFT BLANK 
Island Studies Journal, 16(2), 2021, 3-17

THIS PAGE INTENTIONALLY LEFT BLANK 